\title{
Pseudomonas litoralis sp. nov., isolated from Mediterranean seawater
}

\author{
Javier Pascual, ${ }^{1}$ Teresa Lucena, ${ }^{1}$ María A. Ruvira, ${ }^{1}$ Assunta Giordano, ${ }^{2}$ \\ Agata Gambacorta, ${ }^{2}$ Esperanza Garay, ${ }^{1}$ David R. Arahal, ${ }^{1}$ María J. Pujalte ${ }^{1}$ \\ and M. Carmen Macián ${ }^{1}$ \\ ${ }^{1}$ Departamento de Microbiología y Ecología, Colección Española de Cultivos Tipo (CECT), \\ Universidad de Valencia, 46980 Paterna (Valencia), Spain \\ ${ }^{2}$ Istituto di Chimica Biomolecolare, CNR, Pozzuoli, Italy
}

Correspondence

M. Carmen Macián

m.carmen.macian@uv.es
The genus Pseudomonas Migula 1894 was described originally to include Gram-negative, strictly aerobic rods that are motile by polar flagella. Pseudomonas includes a large number of species isolated from a variety of natural sources including soil, plants, water and clinical specimens, and has become a very heterogeneous taxon that is characterized by a high level of metabolic diversity (Rosselló et al., 1991; Palleroni, 2005).

With the application of modern taxonomic techniques, including rRNA-DNA hybridization studies (Palleroni,

Abbreviations: ASW, artificial sea water; DPG, diphosphatidylglycerol; FAMEs, fatty acid methyl esters; IG, intrageneric groups; ML, maximumlikelihood; MLSA, multilocus sequence analysis; MP, maximumparsimony; NJ, neighbour-joining; PE, phosphatidylethanolamine; PG, phosphatidylglycerol; PHB, polyhydroxybutyrate.

The GenBank/EMBL/DDBJ accession numbers for strain $2 S M 5^{\top}$ (16S rRNA gene, partial $r p o B$ gene, partial $r p o D$ gene, partial gyrB gene), strain 2SM6 (16S rRNA gene, partial rpoB gene, partial rpoD gene, partial gyrB gene), $P$. sabulinigri CECT $7679^{\top}$ (partial rpoB gene, partial rpoD gene, partial gyrB gene) and $P$. pelagia CECT $7689^{\top}$ (partial rpoB gene, partial rpoD gene, partial gyrB gene) are FN908483-FN908496, respectively.

Four supplementary figures and three supplementary tables are available with the online version of this paper.
1984) and phylogenetic studies based on 16S rRNA gene sequence comparisons (Moore et al., 1996; Anzai et al., 2000), the genus Pseudomonas has been split into several genera, some even belonging to different subclasses in the phylum 'Proteobacteria', to accommodate bacteria originally described as species of Pseudomonas. In spite of this, the genus Pseudomonas sensu stricto comprises 120 species with names that have been validly published (http://www. bacterio.cict.fr; Yarza et al., 2010). Based on partial sequences of four housekeeping genes (16S rRNA, gyrB, rpoB and rpoD), Mulet et al. (2010) have recently identified two main intrageneric groups (IG) among species of the genus Pseudomonas, called IG Pseudomonas aeruginosa and IG Pseudomonas fluorescens. In their study, some species were placed on phylogenetic branches apart from both lineages, namely Pseudomonas oryzihabitans, Pseudomonas psychrotolerans, Pseudomonas luteola, Pseudomonas pertucinogena and Pseudomonas pachastrellae; among them, the last two always formed the deepest branch. Although not considered in the study by Mulet et al. (2010), other recently described species closely related to $P$. pertucinogena (Kawai \& Yabuuchi, 1975) and P. pachastrellae (Romanenko et al., 2005) are Pseudomonas pelagia (Hwang et al., 2009), Pseudomonas sabulinigri (Kim et al., 2009), Pseudomonas xiamenensis (Lai \& Shao, 2008) and Pseudomonas xinjiangensis (Liu et al., 
2009). It is interesting to note that although marine environments are not a primary source for the isolation of Pseudomonas spp. (Palleroni, 2005), three of these six species (P. pachastrellae, P. pelagia and P. sabulinigri), were isolated from marine habitats.

During a study of bacterial communities in Mediterranean seawater, two strains, $2 \mathrm{SM} 5^{\mathrm{T}}$ and $2 \mathrm{SM} 6$, were isolated from a seawater sample obtained at a depth of $10 \mathrm{~m}$ off the coast

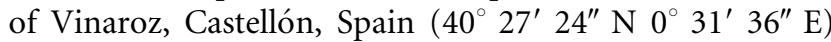
in February, 1990. The seawater was decimally diluted in sterile seawater, plated on marine agar (MA) and incubated at $20-25{ }^{\circ} \mathrm{C}$ for up to 10 days. Pure cultures were obtained from isolated colonies on the plates. The strains were maintained at $-80{ }^{\circ} \mathrm{C}$ as a suspension in marine broth (MB) supplemented with $20 \%$ glycerol. Originally, both strains were included in a numerical taxonomic study with several aerobic marine Gram-negative bacteria obtained from similar samples, in which they remained as isolated operational taxonomic units (Ortigosa et al., 1994).

Recently, the partial $16 \mathrm{~S}$ rRNA gene sequences of strains $2 \mathrm{SM}^{\mathrm{T}}$ and $2 \mathrm{SM} 6$ were determined according to Lucena et al. (2010). A BLAST search in public databases (Zhang et al., 2000) indicated that the almost complete sequences of both strains had a maximum of around $97.3 \%$ similarity to the type strains of $P$. xiamenensis, $P$. pertucinogena and $P$. sabulinigri, thus providing a first indication that both Mediterranean isolates are representatives of a novel species belonging to the genus Pseudomonas. Therefore, we have studied these strains intensely using a polyphasic approach that included phylogenetic analyses based on the $16 \mathrm{~S}$ rRNA gene and three housekeeping genes $(r p o B, r p o D$ and $\operatorname{gyr} B$ ), chemotaxonomic analysis [fatty acid methyl esters (FAMEs), polar lipids, and isoprenoid quinones] and an extensive biochemical and physiological characterization to determine their taxonomic position.

Reference strains used in this study are as follows: $P$. pelagia CECT $7689^{\mathrm{T}}$, P. pertucinogena CECT $7776^{\mathrm{T}}$, P. sabulinigri CECT $7679^{\mathrm{T}}$, P. xiamenensis DSM $22326^{\mathrm{T}}$ and P. xinjiangensis DSM $23391^{\mathrm{T}}$.

Strains $2 \mathrm{SM} 5^{\mathrm{T}}$ and $2 \mathrm{SM} 6$ and reference strains were routinely grown aerobically on MA or MB for $48-72 \mathrm{~h}$ at $20-25{ }^{\circ} \mathrm{C}$, in the dark, for inocula or sample preparation. Unless otherwise indicated, all media were supplemented with half-strength artificial seawater (ASW; $400 \mathrm{mM} \mathrm{NaCl}$, $100 \mathrm{mM} \mathrm{MgSO}_{4} \cdot 7 \mathrm{H}_{2} \mathrm{O}, 20 \mathrm{mM} \mathrm{KCl}$ and $20 \mathrm{mM}$ $\mathrm{CaCl}_{2} \cdot \mathrm{H}_{2} \mathrm{O}$ ). Methods for phenotypic characterization were performed as described previously by Macián et al. (2001, 2005) and Lucena et al. (2010). Both isolates were Gram-negative, strictly aerobic, and oxidase- and catalasepositive. Cell morphology, motility and flagellum arrangement were observed on wet mounts under phase-contrast microscopy (Leica DMRB fluorescence microscopy). Strains $2 \mathrm{SM}^{\mathrm{T}}$ and $2 \mathrm{SM} 6$ were short rods, $0.5-0.9 \mu \mathrm{m}$ wide and $0.8-1.9 \mu \mathrm{m}$ long, motile by a single polar flagellum, as seen after flagella staining according to the method of Heimbrook et al. (1989) (Supplementary Fig.
S1, available in IJSEM Online). On MA plates, they produced smooth, beige colonies with regular edges. They did not accumulate polyhydroxybutyrate (PHB) granules, as shown by staining with Nile Blue A (Smibert \& Krieg, 1994) of cells grown on MA and basal medium agar [BMA; $50 \mathrm{mM}$ Tris/ $\mathrm{HCl}$, pH 7.5; $19 \mathrm{mM} \quad \mathrm{NH}_{4} \mathrm{Cl} ; 0.33 \mathrm{mM}$ $\mathrm{K}_{2} \mathrm{HPO}_{4} \cdot 3 \mathrm{H}_{2} \mathrm{O} ; 0.1 \mathrm{mM} \mathrm{FeSO}_{4} \cdot 7 \mathrm{H}_{2} \mathrm{O}$ and $1.3 \%(\mathrm{w} / \mathrm{v})$ purified agar (Oxoid) on half-strength ASW; Baumann \& Baumann, 1981] plus acetate for 5 days at $25{ }^{\circ} \mathrm{C}$. They were not pigmented on King A and King B medium (King et al., 1954). The Mediterranean isolates were able to grow at 15 and $37{ }^{\circ} \mathrm{C}$, but not at 4 or $40{ }^{\circ} \mathrm{C}$, and both grew without added $\mathrm{NaCl}$ and in up to $15 \%(\mathrm{w} / \mathrm{v})$ total salinity (Table 1). They were able to hydrolyse Tween 80 extracellularly but not alginate, starch, casein, gelatin or DNA after 1 week of incubation on the various media used.

API 20NE and API ZYM test strips (both bioMérieux) and Biolog GN2 microplates were applied to strains $2 \mathrm{SM}^{\mathrm{T}}$ and 2SM6, as well as to reference strains $P$. pelagia CECT $7689^{\mathrm{T}}$, P. pertucinogena CECT $7776^{\mathrm{T}}$, P. sabulinigri CECT $7679^{\mathrm{T}}$, $P$. xiamenensis DSM $22326^{\mathrm{T}}$ and $P$. xinjiangensis DSM $23391^{\mathrm{T}}$. Cell suspensions for the API 20NE and API ZYM systems were made in half-strength ASW and results were recorded in triplicate. With the API 20NE system, strains $2 \mathrm{SM} 5^{\mathrm{T}}$ and $2 \mathrm{SM} 6$ were positive for assimilation of caprate and adipate. In the API ZYM system, both strains were positive for esterase lipase (C8), leucine arylamidase and naphthol-AS-BI-phosphohydrolase, and negative for all other tests. In the Biolog GN2 system after $48 \mathrm{~h}$ incubation, strains $2 \mathrm{SM}^{\mathrm{T}}$ and $2 \mathrm{SM} 6$ oxidized the 12 compounds, mainly organic acids, listed in the species description. Strain $2 \mathrm{SM} 5^{\mathrm{T}}$ weakly oxidized $i$-erythritol, monomethyl succinate, D-galacturonic acid, D-glucuronic acid, succinaminic acid, L-leucine and L-proline; oxidation of dextrin, gentiobiose, alaninamide and thymidine was variable. Strain 2SM6 gave variable results for oxidation of Larabinose, L-rhamnose, citric acid and D-glucuronic acid.

Sole carbon and energy sources, including carbohydrates, organic acids, amino acids and amines, used for growth were tested on BMA according to Baumann \& Baumann (1981). This screening was performed in two independent trials. Substrates that supported growth of both isolates after 15 days incubation at $28{ }^{\circ} \mathrm{C}$ were acetate, pyruvate, propionate, 2-oxoglutarate, succinate, fumarate, malate, lactate, L-glutamate and L-alanine. Strain 2SM6 was also positive for 4 -aminobutyrate and weakly positive for Dglycerate and butyrate. The rest of the carbon sources, from a total of 53, gave negative or variable results (Supplementary Table S1, available in IJSEM Online).

FAME analysis was performed at the CECT, Valencia, Spain. Fatty acids were extracted and prepared according to standard protocols as described for the MIDI Microbial Identification System (Sasser, 1990). Cellular fatty acid content was analysed by GC with an Agilent 6850 chromatographic unit, with the MIDI Microbial Identification System using the RTSBA6 method (MIDI, 2008) and the 
Table 1. Differential characteristics of the novel isolates and strains of related species

Strains: $1, P$. litoralis $2 \mathrm{SM}^{\mathrm{T}}$ and 2SM6; 2, P. xiamenensis DSM $22326^{\mathrm{T}}$; 3, P. pertucinogena CECT $7776^{\mathrm{T}} ; 4$, P. pelagia CECT $7689^{\mathrm{T}}$; 5, P. sabulinigri CECT $7679^{\mathrm{T}}$; 6, P. xinjiangensis DSM $23391^{\mathrm{T}}$; and 7, P. pachastrellae KMM $330^{\mathrm{T}}$. Unless otherwise indicated, all data were obtained concurrently in this study. +, Positive; - , negative; NA, not available; $v$, variable.

\begin{tabular}{|c|c|c|c|c|c|c|c|}
\hline Characteristic & 1 & 2 & 3 & 4 & 5 & 6 & 7 \\
\hline $\begin{array}{l}\text { Reduction of nitrate to nitrite } \\
\text { (API 20NE) }\end{array}$ & - & + & - & + & - & - & $-\star a$ \\
\hline PHB accumulation & - & NA & $-^{b}$ & $-^{c}$ & $\mathrm{NA}$ & $+{ }^{d}$ & $+{ }^{d}$ \\
\hline \multicolumn{8}{|l|}{ Growth at: } \\
\hline $4{ }^{\circ} \mathrm{C}$ & - & $-^{e}$ & $-{ }^{b}$ & $+^{c}$ & $+{ }^{a}$ & $+{ }^{d}$ & $-^{f}$ \\
\hline $40{ }^{\circ} \mathrm{C}$ & - & $+{ }^{e}$ & $+{ }^{b}$ & $-^{c}$ & $-^{a}$ & $+{ }^{d}$ & $+{ }^{f}$ \\
\hline $\begin{array}{l}\text { Maximum salinity tolerance } \\
(\%)\end{array}$ & 15 & $8^{e}$ & $5^{e}$ & $8^{c}$ & $10^{a}$ & $6^{d}$ & $10^{f}$ \\
\hline \multicolumn{8}{|l|}{ Hydrolysis of: } \\
\hline Tween 80 & + & $++^{e}$ & $-{ }^{b}$ & $-^{c}$ & $\mathrm{NA}$ & $+{ }^{d}$ & $+^{f}$ \\
\hline Starch & - & $-^{e}$ & $-^{b}$ & $+{ }^{c}$ & $\mathrm{NA}$ & $-^{d}$ & $f^{f}$ \\
\hline \multicolumn{8}{|l|}{ Enzymic activities (API ZYM): } \\
\hline Alkaline phosphatase & - & - & + & + & + & + & $f^{f}$ \\
\hline Lipase (C14) & - & $\mathrm{V}$ & + & - & + & - & ${ }^{f}$ \\
\hline Trypsin & - & + & + & - & - & + & ${ }^{f}$ \\
\hline \multicolumn{8}{|c|}{ Substrates oxidized in Biolog GN2: } \\
\hline Methyl pyruvate & + & + & - & - & + & + & $++^{a}$ \\
\hline Acetic acid & + & + & + & - & + & + & $-^{a}$ \\
\hline Citric acid & - & + & - & + & + & + & $+{ }^{a}$ \\
\hline Lactic acid & + & + & - & + & + & - & $+{ }^{a}$ \\
\hline Propionic acid & + & + & + & - & + & - & $+{ }^{a}$ \\
\hline Sebacic acid & + & - & - & - & + & - & $+{ }^{a}$ \\
\hline Succinic acid & + & + & + & + & - & + & $+{ }^{a}$ \\
\hline L-Glutamic acid & + & - & + & - & + & - & $-^{a}$ \\
\hline L-Proline & - & + & - & + & + & - & $-^{a}$ \\
\hline \multicolumn{8}{|l|}{ Assimilation of (API 20NE): } \\
\hline Caprate & + & - & - & - & + & - & $+{ }^{a}$ \\
\hline Adipate & + & - & - & - & + & - & $-^{a}$ \\
\hline
\end{tabular}

${ }^{\star}$ Data from: a, Kim et al. (2009); b, Kawai \& Yabuuchi (1975); c, Hwang et al. (2009); d, Liu et al. (2009); e, Lai \& Shao (2008); $f$, Romanenko et al. (2005).

Microbial Identification Sherlock software package version 6.1. . pelagia CECT $7689^{\mathrm{T}}$, $P$. pertucinogena CECT $7776^{\mathrm{T}}, P$. sabulinigri CECT $7679^{\mathrm{T}}$, P. xiamenensis DSM $22326^{\mathrm{T}}$ and $P$. xinjiangensis DSM $23391^{\mathrm{T}}$ were included for comparative purposes. All strains were cultured on tryptone soy agar (TSA) and incubated at $28{ }^{\circ} \mathrm{C}$ for $48 \mathrm{~h}$. Strains $2 \mathrm{SM}^{\mathrm{T}}$ and 2SM6 exhibited very similar profiles in which $\mathrm{C}_{18: 1} \omega 7 \mathrm{c}$ and/ or $\mathrm{C}_{18: 1} \omega 6 c, \mathrm{C}_{16: 0}, \mathrm{C}_{17: 0}$ cyclo and $\mathrm{C}_{16: 1} \omega 7 c$ and/or $\mathrm{C}_{16: 1} \omega 6 c$ were the most abundant fatty acids. The fatty acid profiles of strains $2 \mathrm{SM}^{\mathrm{T}}$ and $2 \mathrm{SM} 6$ were similar to those of related species of the $P$. pertucinogena clade (Table 2). It has to be mentioned that fatty acid compositions of the type strains of $P$. xiamenensis and $P$. xinjiangenesis obtained in our laboratory were in sharp contrast to the original data
Table 2. Cellular fatty acid contents (\%) of $P$. litoralis strains $2 \mathrm{SM}^{\top}$ and $2 \mathrm{SM} 6$ and related species of the intrageneric group ' $P$. pertucinogena'

Strains: 1 , $P$. litoralis $2 \mathrm{SM}^{\mathrm{T}} ; 2$, $P$. litoralis $2 \mathrm{SM} 6 ; 3$, P. xiamenensis DSM $22326^{\mathrm{T}} ; 4$, $P$. pertucinogena CECT $7776^{\mathrm{T}} ; 5$, P. pelagia CECT $7689^{\mathrm{T}}$; 6, P. sabulinigri CECT 7679T; 7, P. xinjiangensis DSM $23391^{\mathrm{T}}$; 8, P. pachastrellae DSM $17577^{\mathrm{T}}$ (Kim et al., 2009). All data are from this study except where marked. All strains were grown on TSA for $48 \mathrm{~h}$ at $28{ }^{\circ} \mathrm{C}$, except for $P$. pachastrellae DSM $17577^{\mathrm{T}}$, which was grown for $72 \mathrm{~h}$ at $30^{\circ} \mathrm{C}$. -, Not detectable; TR, trace amount $(<1 \%)$.

\begin{tabular}{|c|c|c|c|c|c|c|c|c|}
\hline Fatty acid & 1 & 2 & 3 & 4 & 5 & 6 & 7 & 8 \\
\hline \multicolumn{9}{|l|}{ Saturated } \\
\hline $\mathrm{C}_{12: 0}$ & 7.9 & 7.5 & 9.3 & 6.1 & 8.1 & 7.6 & 7.0 & 10.2 \\
\hline $\mathrm{C}_{13: 0}$ & - & TR & - & 1.3 & $\mathrm{TR}$ & $\mathrm{TR}$ & $\mathrm{TR}$ & - \\
\hline $\mathrm{C}_{14: 0}$ & TR & 1.0 & TR & 1.5 & TR & 1.0 & $\mathrm{TR}$ & - \\
\hline $\mathrm{C}_{15: 0}$ & - & - & - & - & - & - & - & 1.8 \\
\hline $\mathrm{C}_{16: 0}$ & 18.5 & 17.4 & 16.1 & 7.9 & 11.8 & 18.5 & 3.3 & 16.9 \\
\hline $\mathrm{C}_{17: 0}$ & $\mathrm{TR}$ & 1.8 & $\mathrm{TR}$ & 3.3 & TR & $\mathrm{TR}$ & - & 1.3 \\
\hline $\mathrm{C}_{18: 0}$ & 1.2 & 1.2 & 1.1 & $\mathrm{TR}$ & 1.0 & 1.5 & TR & 1.1 \\
\hline \multicolumn{9}{|l|}{ Unsaturated } \\
\hline $\mathrm{C}_{15: 1} \omega 6 c$ & $\mathrm{TR}$ & $\mathrm{TR}$ & - & 1.5 & $\mathrm{TR}$ & $\mathrm{TR}$ & $\mathrm{TR}$ & - \\
\hline $\mathrm{C}_{17: 1} \omega 8 c$ & $\mathrm{TR}$ & 1.6 & $\mathrm{TR}$ & 5.3 & 1.1 & $\mathrm{TR}$ & $\mathrm{TR}$ & 1.1 \\
\hline \multicolumn{9}{|l|}{ Branched } \\
\hline iso- $\mathrm{C}_{16: 0}$ & - & - & - & - & - & - & 7.0 & - \\
\hline iso- $\mathrm{C}_{17: 0}$ & TR & TR & - & 1.6 & $\mathrm{TR}$ & 1.2 & - & - \\
\hline iso- $\mathrm{C}_{18: 0}$ & - & - & - & - & - & - & 1.5 & - \\
\hline anteiso- $\mathrm{C}_{17: 0}$ & - & - & - & $\mathrm{TR}$ & - & 1.4 & - & - \\
\hline \multicolumn{9}{|l|}{ Hydroxy } \\
\hline $\mathrm{C}_{10: 0} 3-\mathrm{OH}$ & 3.0 & 2.9 & 3.5 & 3.7 & 3.1 & 2.5 & 1.6 & 2.7 \\
\hline $\mathrm{C}_{11: 0} 3-\mathrm{OH}$ & $\mathrm{TR}$ & $\mathrm{TR}$ & - & 1.7 & TR & $\mathrm{TR}$ & - & - \\
\hline $\mathrm{C}_{12: 0} 3-\mathrm{OH}$ & 4.2 & 3.9 & 4.5 & 3.4 & 4.4 & 4.0 & 4.2 & 4.2 \\
\hline \multicolumn{8}{|l|}{ Cyclo } & - \\
\hline $\mathrm{C}_{17: 0}$ cyclo & 8.9 & 8.5 & 5.1 & 9.0 & 4.4 & 1.2 & 2.0 & 1.4 \\
\hline $\mathrm{C}_{19: 0}$ cyclo $\omega 8 \mathrm{c}$ & 1.8 & 1.4 & 3.0 & 3.8 & 1.3 & $\mathrm{TR}$ & 2.2 & - \\
\hline \multicolumn{9}{|l|}{ Summed features } \\
\hline $\mathrm{C}_{16: 1} \omega 7 c / \mathrm{C}_{16: 1} \omega 6 c$ & 18.1 & 18.3 & 12.8 & 14.3 & 24.6 & 20.4 & 33.3 & 21.6 \\
\hline $\mathrm{C}_{18: 1} \omega 7 c / \mathrm{C}_{18: 1} \omega 6 c$ & 32.6 & 31.8 & 42.5 & 25.7 & 35.4 & 36.8 & 34.5 & 35.2 \\
\hline
\end{tabular}

presented in their species descriptions, most probably due to methodological differences (Supplementary Table S2, available in IJSEM Online).

Analyses of respiratory quinones and polar lipids of the isolates were performed independently at the Istituto di Chimica Biomolecolare, CNR, Pozzuoli, Italy. Quinone analysis of strains $2 \mathrm{SM} 5^{\mathrm{T}}$ and $2 \mathrm{SM} 6$ was done according to Romano et al. (2001) and both isolates had a ubiquinone (Q9) system, which is in agreement with the genus description of Pseudomonas (Palleroni, 2005). Polar lipids of strains $2 \mathrm{SM}^{\mathrm{T}}$ and $2 \mathrm{SM} 6$, together with P. xiamenensis DSM $22326^{\mathrm{T}}$ and $P$. pertucinogena CECT $7776^{\mathrm{T}}$ as references, were extracted from $3.0 \mathrm{~g}$ freeze-dried cells grown in MA for $48 \mathrm{~h}$ at $25{ }^{\circ} \mathrm{C}$. Polar lipids were separated by two-dimensional silicagel TLC and specific functional groups were detected as described previously (Tindall, 1990a, b), whereas total lipid 
(a)

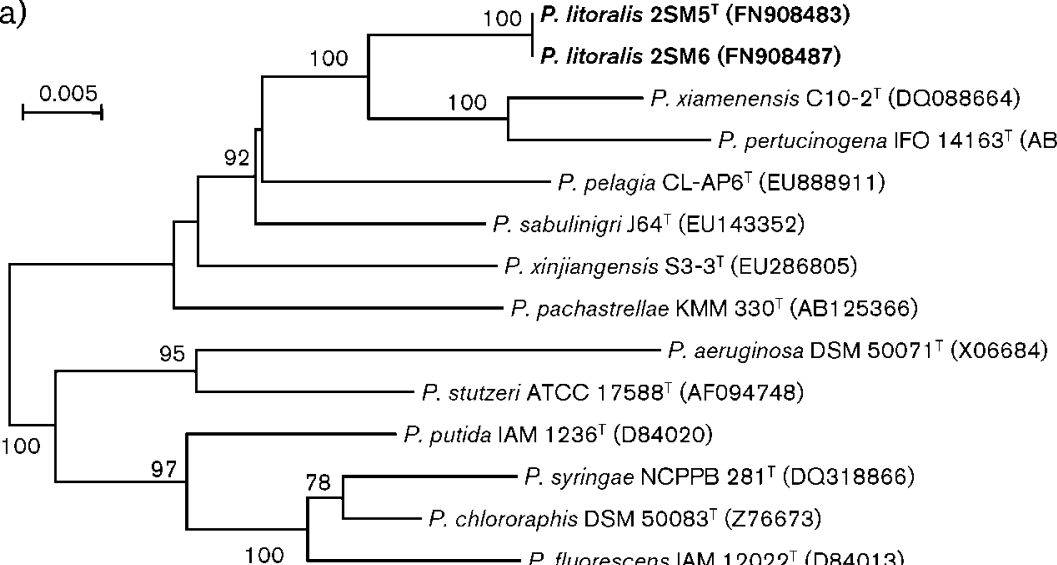

(c)

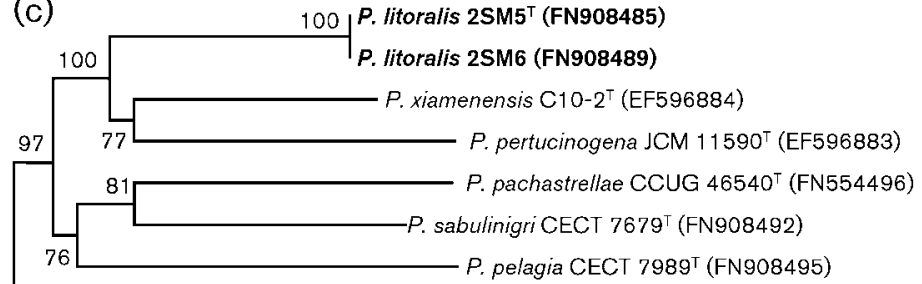

76 P. pelagia CECT 7989 (FN908495)

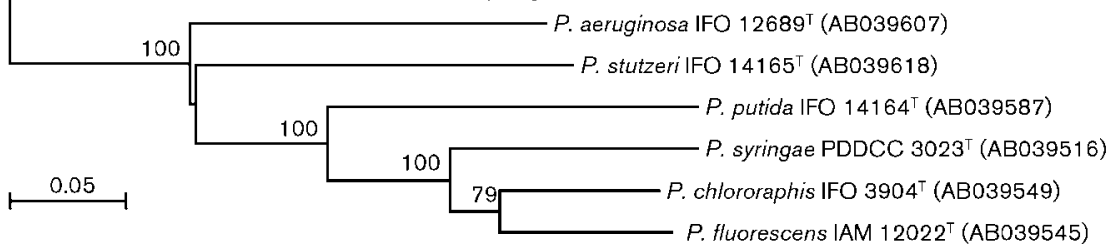

(e)

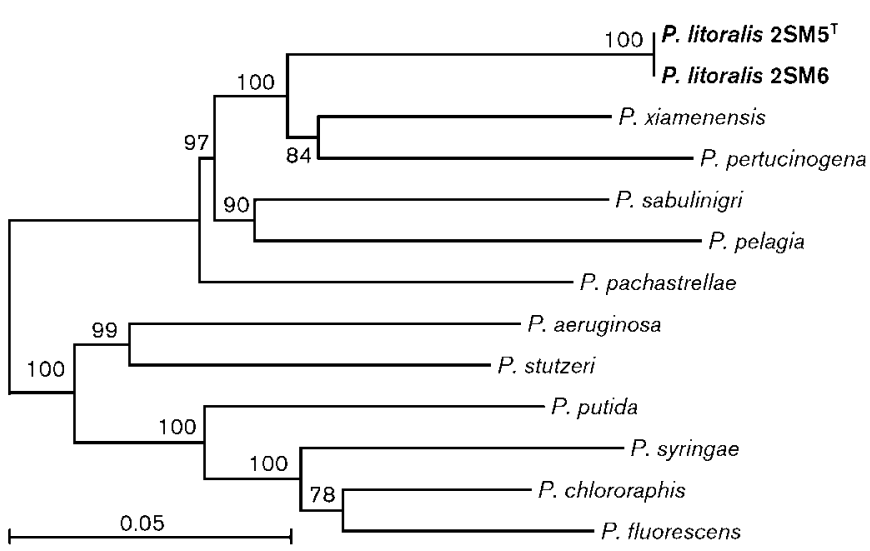

(b)

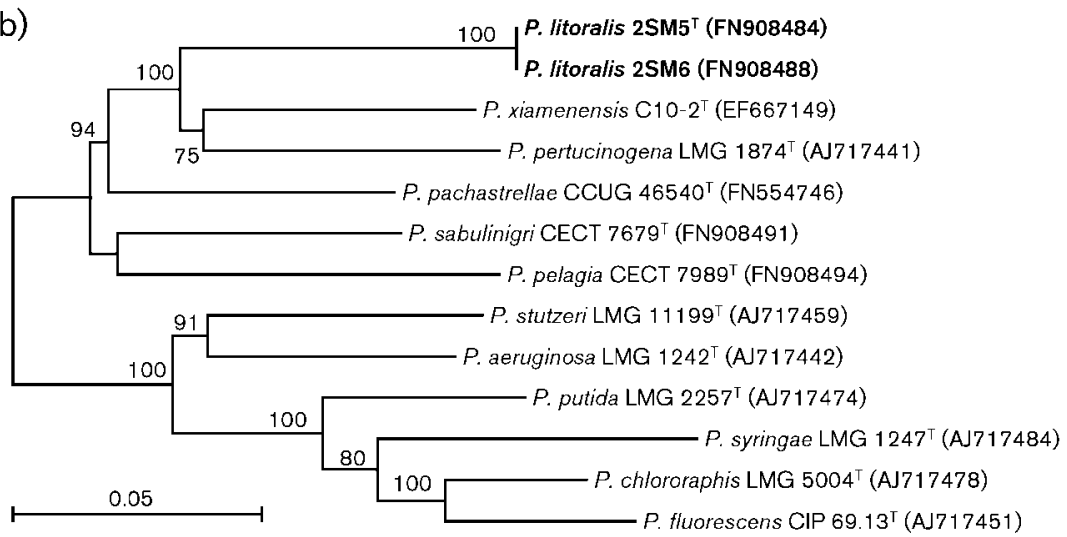

(d)
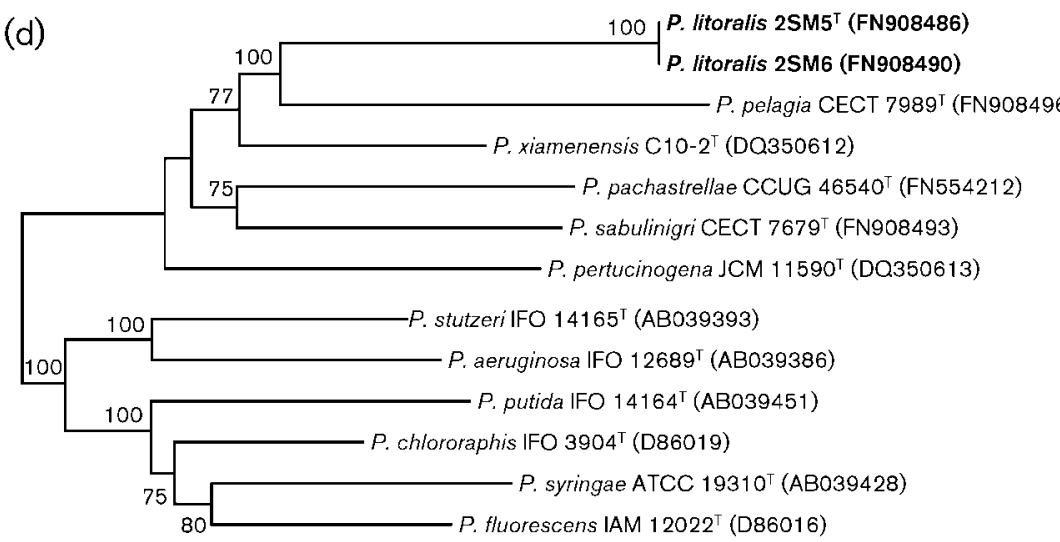

0.05

Fig. 1. Neighbour-joining trees showing the phylogenetic positions of strains $2 S M 5^{\top}$ and 2SM6, and some related Pseudomonas species based on partial 16S rRNA (a), rpoB (b), $r p o D(c)$, gyrB (d) and concatenated gene sequences (e). Bars, 0.005 (a) or 0.05 (b-e) expected nucleotide substitutions per site. Only bootstrap values $\geqslant 75 \%$ are shown $(1000$ resamplings) at branch points. According to $\mathrm{NCBI}$, sequence AJ717459 in Fig. 1(b) originates from strain $P$. stutzeri CIP $11199^{\mathrm{T}}$; however, the correct designation should be $P$. stutzeri LMG $11199^{\top}$. 
material was stained with $0.1 \% \mathrm{Ce}\left(\mathrm{SO}_{4}\right)_{2}$ followed by heating at $100{ }^{\circ} \mathrm{C}$ for $5 \mathrm{~min}$ (Romano et al., 2001). All four strains had phosphatidylethanolamine (PE), diphosphatidylglycerol (DPG) and phosphatidylglycerol (PG) as major components (Supplementary Fig. S2, available in IJSEM Online), which is in agreement with data published previously for Pseudomonas species (Cámara et al., 2007; Romanenko et al., 2005, 2008; Stolz et al., 2007; Xin et al., 2009). In addition, a moderate amount of an unknown phospholipid (PL1) was detected in strains $2 \mathrm{SM}^{\mathrm{T}}$ and 2SM6 and in $P$. xiamenensis DSM $22326^{\mathrm{T}}$ but not in P. pertucinogena CECT $7776^{\mathrm{T}}$. Since some Pseudomonas species exhibit phosphatidylcholine in a similar position, Dragendorff's reagent was applied (analysis done at CECT) but no spot was stained, an indication that quaternary amines are not present.

The presence of 3-hydroxy fatty acids $\left(\mathrm{C}_{10: 0} 3-\mathrm{OH}\right.$ and $\left.\mathrm{C}_{12: 0} 3-\mathrm{OH}\right)$, together with ubiquinone Q-9, and their polar lipid profile confirm the placement of the Mediterranean isolates in the genus Pseudomonas sensu stricto (Oyaizu \& Komagata, 1983).

Isolation of genomic DNA was done using a microbial DNA isolation kit (Ultra Clean; Mo Bio Laboratories). Amplification and partial sequencing of coding genes were performed as described previously by Lucena et al. (2010) (16S rRNA gene), Ait Tayeb et al. (2005) (rpoB gene) and Pascual et al. (2010) ( $r p o D$ and gyrB genes). The almost complete 16S rRNA gene sequences of strains $2 \mathrm{SM} 5^{\mathrm{T}}$ and 2SM6 as well as partial $r p o B, r p o D$ and $g y r B$ gene sequences of $2 \mathrm{SM}^{\mathrm{T}}, 2 \mathrm{SM} 6, P$. sabulinigri CECT $7679^{\mathrm{T}}$ and P. pelagia CECT $7689^{\mathrm{T}}$ were obtained in this study. The rest of the sequences analysed in this paper were obtained from public databases and their accession numbers are displayed in the phylogenetic trees.

The lengths of the fragments used for further analysis ranged from 1403 to $1537 \mathrm{nt}$ (16S rRNA gene), 909 to $1140 \mathrm{nt}$ $(r p o B), 723$ to $857 \mathrm{nt}(r p o D), 798$ to $1164 \mathrm{nt}(\mathrm{gyrB})$, and 3882 to $4569 \mathrm{nt}$ (four concatenated genes). Multiple sequence alignments were obtained using CLUSTAL_X (Thompson et al., 1997) taking into account the corresponding amino acid alignments for protein-coding genes. Nucleotide sequence alignments were inspected visually to identify positions of uncertain alignment, usually at the ends of the sequences, to be corrected or omitted for further analysis.

Phylogenetic analysis was performed using the program PAUP $^{*}$ version 4.0b10 (Swofford, 2002). Neighbour-joining (NJ; with Kimura's two-parameter correction), maximumparsimony (MP; heuristic search option) and maximumlikelihood (ML) analyses were done for each of the genes and the concatenated sequence. Since the lengths of the sequences used were uneven, analyses were performed using a pairwise deletion method for gaps and missing sites, using all available comparative data from each sequence pair. For ML, the optimal models of nucleotide substitution were estimated through the program jModelTest (Posada, 2008) using the Akaike Information Criterion. Bootstrap analyses were performed using 1000 replications for $\mathrm{NJ}$ and $\mathrm{MP}$, and 500 replications for ML. The different trees obtained with the NJ, MP and ML methods are shown in Fig. 1, and Supplementary Figs S3 and S4 (available in IJSEM Online), respectively. Supplementary Table S3 shows the pairwise sequence similarities (\%) of each dataset. All phylogenetic analyses of the $16 \mathrm{~S}$ rRNA, $r p o B, r p o D$ and $g y r B$ genes individually and concatenated, display strains $2 \mathrm{SM} 5^{\mathrm{T}}$ and 2SM6 together. Irrespective of the tree reconstruction method applied, all trees analysed except for the gyrB trees showed the type strains of $P$. xiamenensis and $P$. pertucinogena as the nearest node to strains $2 \mathrm{SM} 5^{\mathrm{T}}$ and $2 \mathrm{SM} 6$, with all four strains forming a robust clade supported by high bootstrap values. The relative positions of the rest of the species belonging to the $P$. pertucinogena clade, $P$. pachastrellae, $P$. pelagia, $P$. sabulinigri and $P$. xinjiangensis, varied depending on the method applied (NJ, MP and ML) and the set of sequences used. Amino acid sequences were also analysed through MP and NJ methods applying the Poisson model (not shown). In all eight trees obtained, strains $2 \mathrm{SM} 5^{\mathrm{T}}$ and $2 \mathrm{SM} 6$ joined the same immediate neighbours as in the nucleotide-based trees, although other aspects of the tree topologies could be different.

Since multilocus sequence analysis (MLSA) uses a higher number of nucleotides than a single gene analysis, and avoids possible effects that the horizontal gene transfer could generate on phylogenetic relationships, it could be considered that MLSA shows the correct evolutionary pattern among the species included in this study. Even so, screening of recombination events in the four genes studied by using the RDP3 Beta 27 program (Martin et al., 2005) and according to Pascual et al. (2010), did not reveal any signal of horizontal gene transfer in the sequences of each gene analysed.

The similarity values obtained between isolates $2 \mathrm{SM} 5^{\mathrm{T}}$ and 2SM6 in all four gene sequences analysed individually was always $100 \%$, thus confirming their phylogenetic placement in the same species (Supplementary Table S3). The highest interspecific sequence similarities found between both isolates and their phylogenetic neighbours in the $P$. pertucinogena clade were $97.3 \%$ (16S rRNA), $88.7 \%$ $(r p o B), 82.3 \%(r p o D), 84.3 \%(g y r B)$ and $89.4 \%$ (MLSA of four genes concatenated) to $P$. xiamenensis in all cases (Supplementary Table S3). On the one hand, the maximum interspecific similarity found with the $16 \mathrm{~S}$ rRNA gene sequences is slightly above the generally accepted threshold value $(97 \%)$ that differentiates prokaryotic species (Tindall et al., 2010). On the other hand, the maximum interspecific similarities found with the housekeeping genes individually are clearly lower than the maximum interspecific similarity found among the rest of the Pseudomonas species analysed, 93.6\% (rpoB), 87.1\% ( $r p o D), 88.8 \%(g y r B)$ and $92.6 \%$ (MLSA) (Supplementary Table S3). Furthermore, the maximum interspecific values obtained in this work are in agreement with those previously observed (Lai \& Shao, 2008; Mulet et al., 2010), thus confirming the separate species status of strains 
$2 \mathrm{SM}^{\mathrm{T}}$ and 2SM6. Additionally, analysis of amino acid sequences, which are typically more conserved than their nucleotide counterparts, confirmed the results already presented. The intraspecific amino acid sequence distance between strains $2 \mathrm{SM}^{\mathrm{T}}$ and $2 \mathrm{SM} 6$ was $100 \%$ in all three protein-coding genes. On the other hand, the highest interspecific amino acid sequence similarity found between both isolates and their closest phylogenetic neighbours was $96.3 \%(r p o B), 82.6 \%(r p o D)$ and $93.7 \%(g y r B)$. These values are lower than those found among other species belonging to the $P$. pertucinogena clade (data not shown).

As shown in Table 1, our Mediterranean isolates can be distinguished from their closest phylogenetic neighbour $P$. xiamenensis based on several traits: nitrate reduction ability; growth at $40{ }^{\circ} \mathrm{C}$; salt tolerance range; presence of trypsin activity; oxidation of citric acid, sebacic acid, Lglutamic acid and L-proline in Biolog GN2; and assimilation of caprate and adipate in API 20NE strips. Moreover, strains $2 \mathrm{SM}^{\mathrm{T}}$ and $2 \mathrm{SM} 6$ could be also distinguished from the rest of the species in the $P$. pertucinogena clade by no less than seven differential characteristics including, among others, the inability of our isolates to accumulate PHB, to grow at 4 and $40{ }^{\circ} \mathrm{C}$, and their moderate salt tolerance (up to $15 \% \mathrm{NaCl}$ ) (Table 1).

Phenotypic, including chemotaxonomic, and phylogenetic results presented here support the proposal of strains $2 \mathrm{SM}^{\mathrm{T}}$ and 2SM6 as members of a novel species of Pseudomonas, Pseudomonas litoralis sp. nov., with strain $2 \mathrm{SM} 5^{\mathrm{T}}$ as the type strain.

\section{Description of Pseudomonas litoralis sp. nov.}

Pseudomonas litoralis (li.to.ra'lis. L. fem. adj. litoralis of or belonging to the seashore).

Cells are Gram-negative, short rods, $0.5-0.9 \mu \mathrm{m}$ wide and $0.8-1.9 \mu \mathrm{m}$ long, motile by a single polar flagellum. Chemoorganotrophic, strictly aerobic, and oxidase- and catalasepositive. Grows on MA producing smooth, beige colonies with regular edges. Does not accumulate PHB granules and is not pigmented on King A or King B media. Both isolates grow at 15 and $37{ }^{\circ} \mathrm{C}$, but not at 4 or $40{ }^{\circ} \mathrm{C}$. Growth is observed without added $\mathrm{NaCl}$ and in up to $15 \%$ total salinity. In API 20NE, positive for assimilation of caprate and adipate and negative for nitrate reduction, indole production, glucose fermentation, arginine dihydrolase, urease, hydrolysis of aesculin and gelatin, $\beta$-galactosidase, and assimilation of D-glucose, L-arabinose, D-mannose, Dmannitol, $N$-acetylglucosamine, maltose, potassium gluconate, malic acid, trisodium citrate and phenylacetic acid. Hydrolyses Tween 80 extracellularly but not alginate, starch, casein, gelatin or DNA. In the API ZYM system, positive for esterase lipase (C8), leucine arylamidase and naphthol-ASBI-phosphohydrolase. In the Biolog GN2 system, oxidizes Tween 40, Tween 80, methyl pyruvate, acetic acid, DL-lactic acid, propionic acid, sebacic acid, succinic acid, bromosuccinic acid, D-alanine, L-alanine and L-glutamic acid. On BMA, utilizes acetate, pyruvate, propionate, 2-oxoglutarate, succinate, fumarate, malate, lactate, L-glutamate and Lalanine, out of 53 carbon sources tested, as sole carbon and energy sources. The most abundant FAMEs are $\mathrm{C}_{18: 1} \omega 7 \mathrm{c}$ and/or $\mathrm{C}_{18: 1} \omega 6 c, \mathrm{C}_{16: 0}, \mathrm{C}_{17: 0}$ cyclo and $\mathrm{C}_{16: 1} \omega 7 c$ and/or $\mathrm{C}_{16: 1} \omega 6 c$. Ubiquinone Q-9 is the isoprenoid quinone, and diphosphatidylglycerol, phosphatidylethanolamine and phosphatidylglycerol are major polar lipids plus a moderate amount of an unknown phospholipid and traces of another unknown phospholipid and an unknown polar lipid.

The type strain is $2 \mathrm{SM}^{\mathrm{T}}\left(=\mathrm{CECT} 7670^{\mathrm{T}}=\mathrm{KCTC} 23093^{\mathrm{T}}\right)$, isolated from a seawater sample obtained at a depth of $10 \mathrm{~m}$ off the coast of Vinaroz, Castellón, Spain. Strain 2SM6 (=CECT $7669=$ KCTC 23094), isolated from the same source, is a reference strain.

\section{Acknowledgements}

This work has been supported by Spanish Ministerio de Educación y Ciencia project CGL2010-18134/BOS to M. J.P.

\section{References}

Ait Tayeb, L. A., Ageron, E., Grimont, F. \& Grimont, P. A. (2005). Molecular phylogeny of the genus Pseudomonas based on rpoB sequences and application for the identification of isolates. Res Microbiol 156, 763-773.

Anzai, Y., Kim, H., Park, J. Y., Wakabayashi, H. \& Oyaizu, H. (2000). Phylogenetic affiliation of the pseudomonads based on 16S rRNA sequence. Int J Syst Evol Microbiol 50, 1563-1589.

Baumann, P. \& Baumann, L. (1981). The marine Gram-negative eubacteria: genera Photobacterium, Beneckea, Alteromonas, Pseudomonas and Alcaligenes. In The Prokaryotes, vol. II, pp. 1302-1331. Edited by M. P. Starr, H. Stolp, H. G. Trüper, A. Balows \& H. Schleger. Berlin, Heidelberg: Springer-Verlag.

Cámara, B., Strömpl, C., Verbarg, S., Spröer, C., Pieper, D. H. \& Tindall, B. J. (2007). Pseudomonas reinekei sp. nov., Pseudomonas moorei sp. nov. and Pseudomonas mohnii sp. nov., novel species capable of degrading chlorosalicylates or isopimaric acid. Int J Syst Evol Microbiol 57, 923-931.

Heimbrook, M. E., Wang, W. L. \& Campbell, G. (1989). Staining bacterial flagella easily. J Clin Microbiol 27, 2612-2615.

Hwang, C. Y., Zhang, G. I., Kang, S. H., Kim, H. J. \& Cho, B. C. (2009). Pseudomonas pelagia sp. nov., isolated from a culture of the Antarctic green alga Pyramimonas gelidicola. Int J Syst Evol Microbiol 59, 30193024.

Kawai, Y. \& Yabuuchi, E. (1975). Pseudomonas pertucinogena sp. nov., an organism previously misidentified as Bordetella pertussis. Int J Syst Bacteriol 25, 317-323.

Kim, K. H., Roh, S. W., Chang, H. W., Nam, Y. D., Yoon, J. H., Jeon, C. O., Oh, H. M. \& Bae, J. W. (2009). Pseudomonas sabulinigri sp. nov., isolated from black beach sand. Int J Syst Evol Microbiol 59, 38-41.

King, E. O., Ward, M. K. \& Raney, D. E. (1954). Two simple media for the demonstration of pyocyanin and fluorescin. J Lab Clin Med 44, 301-307.

Lai, Q. \& Shao, Z. (2008). Pseudomonas xiamenensis sp. nov., a denitrifying bacterium isolated from activated sludge. Int J Syst Evol Microbiol 58, 1911-1915.

Liu, M., Luo, X., Zhang, L., Dai, J., Wang, Y., Tang, Y., Li, J., Sun, T. \& Fang, C. (2009). Pseudomonas xinjiangensis sp. nov., a moderately 
thermotolerant bacterium isolated from desert sand. Int J Syst Evol Microbiol 59, 1286-1289.

Lucena, T., Pascual, J., Garay, E., Arahal, D. R., Macián, M. C. \& Pujalte, M. J. (2010). Haliea mediterranea sp. nov., a marine gammaproteobacterium. Int J Syst Evol Microbiol 60, 1844-1848.

Macián, M. C., Ludwig, W., Aznar, R., Grimont, P. A., Schleifer, K. H., Garay, E. \& Pujalte, M. J. (2001). Vibrio lentus sp. nov., isolated from Mediterranean oysters. Int J Syst Evol Microbiol 51, 1449-1456.

Macián, M. C., Arahal, D. R., Garay, E., Ludwig, W., Schleifer, K.-H. \& Pujalte, M. J. (2005). Thalassobacter stenotrophicus gen. nov., sp. nov., a novel marine $\alpha$-proteobacterium isolated from Mediterranean sea water. Int J Syst Evol Microbiol 55, 105-110.

Martin, D. P., Williamson, C. \& Posada, D. (2005). RDP2: recombination detection and analysis from sequence alignments. Bioinformatics 21, 260-262.

MIDI (2008). Sherlock Microbial Identification System Operating Manual, version 6.1. Newark, DE: MIDI Inc.

Moore, E. R. B., Mau, M., Arnscheidt, A., Böttger, E. C., Hutson, R. A., Collins, M. D., Van de Peer, Y., De Wachter, R. \& Timmis, K. N. (1996). The determination and comparison of the 16S rRNA gene sequences of species of the genus Pseudomonas (sensu stricto) and estimation of the natural intrageneric relationship. Syst Appl Microbiol 19, 478-492.

Mulet, M., Lalucat, J. \& García-Valdés, E. (2010). DNA sequencebased analysis of the Pseudomonas species. Environ Microbiol 12, 1513-1530.

Ortigosa, M., Garay, E. \& Pujalte, M.-J. (1994). Numerical taxonomy of aerobic, Gram-negative bacteria associated with oysters and surrounding seawater of the Mediterranean coast. Syst Appl Microbiol 17, 589-600.

Oyaizu, H. \& Komagata, K. (1983). Grouping of Pseudomonas species on the basis of cellular fatty acid composition and the quinone system with special reference to the existence of 3-hydroxy fatty acids. J Gen Appl Microbiol 29, 17-40.

Palleroni, N. J. (1984). Genus I. Pseudomonas Migula 1894. In Bergey's Manual of Systematic Bacteriology, vol. 1, pp. 141-199. Edited by N. R. Krieg \& J. G. Holt. Baltimore: Williams \& Wilkins.

Palleroni, N. J. (2005). Genus I. Pseudomonas Migula 1894. In Bergey's Manual of Systematic Bacteriology (The Proteobacteria), part B (The Gammaproteobacteria), 2nd edn, vol. 2, pp. 323-379. Edited by D. J. Brenner, N. R. Krieg, James T. Staley \& G. M. Garrity. New York: Springer.

Pascual, J., Macián, M. C., Arahal, D. R., Garay, E. \& Pujalte, M. J. (2010). Multilocus sequence analysis of the central clade of the genus Vibrio by using the $16 \mathrm{~S}$ rRNA, recA, pyrH, rpoD, gyrB, rctB and toxR genes. Int J Syst Evol Microbiol 60, 154-165.

Posada, D. (2008). jModelTest: phylogenetic model averaging. Mol Biol Evol 25, 1253-1256.
Romanenko, L. A., Uchino, M., Falsen, E., Frolova, G. M., Zhukova, N. V. \& Mikhailov, V. V. (2005). Pseudomonas pachastrellae sp. nov., isolated from a marine sponge. Int J Syst Evol Microbiol 55, 919924.

Romanenko, L. A., Uchino, M., Tebo, B. M., Tanaka, N., Frolova, G. M. \& Mikhailov, V. V. (2008). Pseudomonas marincola sp. nov., isolated from marine environments. Int J Syst Evol Microbiol 58, 706-710.

Romano, I., Nicolaus, B., Lama, L., Trabasso, D., Caracciolo, G. \& Gambacorta, A. (2001). Accumulation of osmoprotectants and lipid pattern modulation in response to growth conditions by Halomonas pantelleriense. Syst Appl Microbiol 24, 342-352.

Rosselló, R., Garcia-Valdés, E., Lalucat, J. \& Ursing, J. (1991). Genotypic and phenotypic diversity of Pseudomonas stutzeri. Syst Appl Microbiol 14, 150-157.

Sasser, M. (1990). Identification of bacteria by gas chromatography of cellular fatty acids, MIDI Technical Note 101. Newark, DE: MIDI Inc.

Smibert, R. M. \& Krieg, N. R. (1994). Phenotypic characterization. In Methods for General and Molecular Bacteriology, pp. 607-654. Edited by P. Gerhardt, R. G. E. Murray, W. A. Wood \& N. R. Krieg. Washington, DC: American Society for Microbiology.

Stolz, A., Busse, H.-J. \& Kämpfer, P. (2007). Pseudomonas knackmussii sp. nov. Int J Syst Evol Microbiol 57, 572-576.

Swofford, D. L. (2002). PAUP*: Phylogenetic analysis using parsimony (and other methods), version 4. Sunderland, MA: Sinauer Associates.

Thompson, J. D., Gibson, T. J., Plewniak, F., Jeanmougin, F. \& Higgins, D. G. (1997). The CLUSTAL_X windows interface: flexible strategies for multiple sequence alignment aided by quality analysis tools. Nucleic Acids Res 25, 4876-4882.

Tindall, B. J. (1990a). A comparative study of the lipid composition of Halobacterium saccharovorum from various sources. Syst Appl Microbiol 13, 128-130.

Tindall, B. J. (1990b). Lipid composition of Halobacterium lacusprofundi. FEMS Microbiol Lett 66, 199-202.

Tindall, B. J., Rosselló-Móra, R., Busse, H.-J., Ludwig, W. \& Kämpfer, P. (2010). Notes on the characterization of prokaryote strains for taxonomic purposes. Int J Syst Evol Microbiol 60, 249-266.

Xin, Y. H., Zhang, D. C., Liu, H. C., Zhou, H. L. \& Zhou, Y. G. (2009). Pseudomonas tuomuerensis sp. nov., isolated from a bird's nest. Int $J$ Syst Evol Microbiol 59, 139-143.

Yarza, P., Ludwig, W., Euzéby, J., Amann, R., Schleifer, K. H., Glöckner, F. O. \& Rosselló-Móra, R. (2010). Update of the All-Species Living Tree Project based on 16S and 23S rRNA sequence analyses. Syst Appl Microbiol 33, 291-299.

Zhang, Z., Schwartz, S., Wagner, L. \& Miller, W. (2000). A greedy algorithm for aligning DNA sequences. J Comput Biol 7, 203214. 